\title{
Pengaruh Profitabilitas, Tangibilitas, Risiko Bisnis, Pajak, Non Debt Tax Shield terhadap Struktur Modal Serta Implikasinya terhadap Nilai Perusahaan
}

\author{
Yuliandi ${ }^{1}$, J.M.V.Mulyadi², Muhammad Yusuf ${ }^{3}$ \\ 1, 2 Universitas Pancasila, Jl. Raya Lenteng Agunug, Jagakarsa, Jakarta Selatan, 12640. \\ ${ }^{3}$ Indonesia Banking School (IBS), Jl. Kemang Raya No. 35 Kebayoran baru - Jakarta Selatan - 12730
}

I N F O A R T I K E L

JEL Classification:

$H 25$,

016 ,

M41

\section{Keywords:}

profitability,

tangibility,

business risk,

tax, non debt tax shield,

and corporate value.
A B S T R A C T

This study aims to examine the extent of the effect of profitability, tangibility, business risk, tax and non-debt tax shield on capital structure, and its implications for the value of the company. The sample used in this study were 23 mining companies listed on the Indonesian stock exchange in 2010-2014. The formulation of the problem posed in this study is how much influence the profitability, tangibility, business risk, tax and non-debt tax shield on capital structure, and the influence of capital structure to the company's value partially and simultaneously. The sampling technique in this study using purposive sampling. The method used in this study using multiple linear regression and simple linear regression by using SPSS 21. The results of this study concluded that simultaneous independent variables affect the dependent variable. Partially profitability, tangibility, business risk, no significant effect on the capital structure, while the tax, non-debt tax shield a significant effect on capital structure and capital structure does not significantly influence the value of the company at a mining company listed on the stock exchanges Indonesia the period 2010 to 2014.

\section{A B S T R A $\mathbf{K}$}

Studi ini bertujuan untuk meneliti sejauhmana pengaruh profitabilitas, tangibilitas, risiko bisnis, pajak dan non debt tax shield terhadap struktur modal, dan implikasinya terhadap nilai perusahaan. Sampel yang di gunakan dalam penelitian ini sebanyak 23 perusahaan pertambangan yang terdaftar di bursa efek indonesia periode 2010-2014. Rumusan masalah yang diajukan dalam penelitian ini adalah seberapa besar pengaruh profitabilitas, tangibilitas, risiko bisnis, pajak dan non debt tax shield terhadap struktur modal, dan pengaruh struktur modal terhadap nilai perusahaan secara parsial dan simultan. Teknik pengambilan sampel dalam penelitian ini menggunakan purposive sampling. Metode yang digunakan dalam penelitian ini menggunakan regresi linier berganda dan regresi linier sederhana dengan menggunakan SPSS 21. Hasil penelitian ini menyimpulkan bahwa secara simultan variabel independen berpengaruh terhadap variabel dependen. Secara parsial profitabilitas, tangibilitas, risiko bisnis, tidak berpengaruh signifikan terhadap struktur modal, sedangkan pajak, non debt tax shield berpengaruh signifikan terhadap struktur modal dan struktur modal tidak berpengaruh signifikan terhadap nilai perusahaan pada perusahaan pertambangan yang tercatat pada bursa efek indonesia periode tahun 2010 sampai 2014.

*Email Korespondensi: 'yuliandi_spp@yahoo.com, 2mulyadijmv@gmail.com,33yusuf_moch202@yahoo.com 


\section{Pendahuluan}

Dunia usaha terus berkembang seiring dengan meningkatnya perekonomian baik ditingkat lokal maupun ditingkat global. Di era globalisasi ini persaingan semakin ketat, perusahaan dituntut untuk meningkatkan daya saing baik itu produk, teknologi, sumberdaya manusia dan promosi, managemen sebagai penanggungjawab mengelolah suatu entitas bisnis harus dapat mengambil keputusan dengan tepat, cepat baik itu keputusan yang bersifat financial maupun non financial.

Salah satu keputusan yang bersifat financial yaitu bagaimana cara mengelolah dana dengan baik, untuk mendapatkan tambahan dana atau modal yang digunakan untuk mengembangkan bisnis, tambahan modal bisa diperoleh dari beberapa sumber, seperti dari pasar modal, perbankan atau dari setoran modal pemegang saham.kebijakan mengenai struktur modal melibatkan trade off antara resiko dengan manfaat, dengan menambah hutang akan memperbesar resiko perusahaan tetapi juga dapat memperbesar tingkat laba dengan adanya pertumbuhan dari penggunaan dana pinjaman tersebut.

Struktur modal perusahaan adalah pembiayaan permanen yang terdiri dari hutang jangka panjang, saham preferen, dan modal pemegang saham. Menurut Weston dan Brigham (1997) struktur keuangan adalah cara bagaimana perusahaan membiayai aktivanya dan dapat dilihat pada neraca yang terdiri dari hutang jangka pendek, hutang jangka panjang dan modal pemegang saham. Jadi, struktur modal suatu perusahaan hanya sebagian dari struktur keuangannya.

Biaya modal yang timbul dari keputusan pendanaan tersebut merupakan konsekuensi yang secara langsung timbul dari keputusan yang dilakukan manajer. Ketika manajer menggunakan hutang, jelas biaya modal yang timbul sebesar bunga yang dibebankan oleh kreditur, sedangkan jika manajer menggunakan dana internal atau dana sendiri akan timbul (opportunity cost) dari dana atau modal sendiri yang digunakan. Modal adalah salah satu hal yang paling penting dalam menjalankan bisnis, untuk itu struktur modal perlu dikaji lebih mendalam, selama tingkat hutang dapat meningkatkan pertumbuhan laba maka diharapkan meningkatkan harga saham, tetapi hutang yang tinggi juga meningkatkan resiko perusahaan.

Penelitian mengenai pengaruh profitabilitas terhadap struktur modal pernah dilakukan oleh Nguyen (2014), Nurita dan Mawardi (2013), Liem dkk (2013), Li-Ju dan Shun-yu (2014), Widodo dkk (2014), menunjukkan bahwa profitabilitas berpengaruh negative terhadap struktur modal, sedangkan untuk variabel tangibility sedangkan penelitian yang dilakukan oleh Widodo dkk (2014), Nguyen (2014) menyatakan bahwa tangibility berpengaruh positif terhadap struktur modal atau dengan kata lain membaiknya tangibilitas akan mampu memperbaiki struktur modalnya. Penelitian mengenai pengaruh risiko usaha dengan struktur modal pernah dilakukan oleh Jeni Anwar dkk (2014) menunjukkan bahwa adanya pengaruh negatif antara risiko bisnis dengan struktur modal.

Penelitian mengenai pengaruh pajak terhadap struktur modal dilakukan oleh Anisa dan Djumahir (2014), Nguyen (2014), Dewi dan Bajra (2013) dan Li-Ju dan Shun-Yu (2014), menemukan bahwa pajak berpengaruh positif terhadap struktur modal sedangkan penelitian yang dilakukan oleh Chaerunisa dan Farah (2014) menemukan pajak tidak berpengaruh terhadap struktur hutang. Penelitian yang dilakukan oleh Hermuningsih (2012) yang meneliti pengaruh profitabilitas, growth opportunity, struktur modal terhadap nilai perusahaan memperoleh hasil bahwa profitabilitas, growth opportunity dan struktur modal berpengaruh positif dan signifikan terhadap nilai perusahaan, Rahmawati (2015) menyatakan bahwa ukuran perusahaan, profitabilitas, struktur modal dan keputusan investasi secara simultan berpengaruh terhadap nilai perusahaan.

Tujuan dari penelitian ini adalah untuk membuktikan bahwa terdapat pengaruh profitabilitas, tangibilitas, business risk, pajak 
dan non debt tax shield terhadap struktur modal, dan implikasinya terhadap nilai perusahaan.

\section{Telaah Teori dan Pengembangan Hipotesis}

Struktur modal dapat dibagi menjadi dua kelompok, yaitu hutang dan ekuitas (Ross,2006), struktur modal dapat diukur dengan membandingkan antara total hutang dengan total ekuitas (modal sendiri). Menurut Mardiyanto (2009:51) struktur modal adalah: "Komposisi dan proporsi hutang jangka panjang dan ekuitas (saham preferen dan saham biasa) yang ditetepkan perusahaan". Sedangkan menurut Riyanto (2008) struktur modal adalah :"Pembelanjaan permanen yang mencerminkan perimbangan antara hutang jangka panjang dan modal sendiri”.

Penelitian struktur modal yang dilakukan oleh Franco Modigliani dan Merton H.Miller pada tahun 1958, telah memberikan definisi operasional atas modal dan teori investasi yang bisa direalisasikan. Teori keuangan bisnis dalam pengertian modern dimulai dengan Modigliani dan Miller (1958). Sebelum teori Modigliani dan Miller, belum ada teori struktur modal yang dapat diterima. Mereka mulai dengan asumsi bahwa perusahaan memiliki bagian tertentu dari arus kas yang diharapkan. Ketika perusahaan memilih proporsi tertentu dari utang dan ekuitas untuk pendanaan, hal tersebut dilakukan bertujuan untuk membagi arus kas kepadapara investor. Investor dan perusahaan diasumsikan memiliki akses yang sama ke pasar keuangan, dimana diharapkan membentuk leverage sendiri (homemade leverage).

Modigliani-Miller menyimpulkan bahwa dengan penggunaan hutang (leverage) akan meningkatkan nilai perusahaan karena adanya penghematan pajak. Penghematan pajak ini karena penghasilan kena pajak akan berkurang akibat dari penggunaan hutang (tax deductible), sehingga jumlah pajak yang dibayarkan lebih kecil dibandingkan perusahaan yang tidak memiliki hutang Trade-off theory menjelaskan bahwa jika posisi struktur modal berada di bawah titik optimal maka setiap penambahan hutang akan meningkatkan nilai perusahaan.
Sebaliknya, jika posisi struktur modal berada di atas titik optimal maka setiap penambahan hutang akan menurunkan nilai perusahaan. Oleh karena itu, dengan asumsi titik target struktur modal optimal belum tercapai, maka berdasarkan trade-off theory memprediksi adanya hubungan yang positif terhadap nilai perusahaan.

Pecking order theory mengasumsikan bahwa tidak ada target strukturmodal.Perusahaanperusahaan memilih modal sesuai dengan urutan berikut: pendanaan internal, hutang, dan ekuitas ( Myers dan Majluf. 1984) berpendapat adanya asimetri informasi antara manajer (orang dalam) dan investor (luar). Mereka berpendapat bahwa manajer memiliki informasi lebih daripada investor dan bertindak mendukung pemegang saham lama (Li-Ju dan Shun-Yu.2013).

Teori sinyal menunjukkan adanya asimetri informasi antara manajemen perusahaan dan pihak-pihak yang berkepentingan dengan informasi tersebut. Teori signalling pertama kali diperkenalkan oleh Ross (1979) yang menekankan pada pentingnya informasi untuk dibagikan perusahaan terhadap keputusan investasi bagi pihak di luar perusahaan.

\section{Pengaruh Profitabilitas terhadap Struktur Modal}

Hubungan profitabilitas dengan tingkat hutang dapat dijelaskan bahwa perusahaan yang mempunyai profitabilitas tinggi mencerminkan bahwa perusahaan tersebut mampu untuk melunasi hutang-hutangnya sehingga pihak kreditur akan lebih percaya untuk memberikan hutang kepada perusahaan yang mempunyai tingkat profitabilitas yang tinggi dibandingkan dengan perusahaan yang profitabilitasnya rendah. Perusahaan dengan rate of return yang tinggi cenderung menggunakan proporsi hutang yang relatif kecil, karena dengan rate of return yang tinggi, kebutuhan dana dihasilkan secara internal dari laba yang ditahan (Brigham dan Houston, 2006).

Profitabilitas yang tinggi juga akan meningkatkan laba ditahan, laba ditahan dapat digunakan untuk pembayaran deviden dan sumber pendanaan untuk melakukan investasi, 
hal ini akan memperkecil rasio hutang. Penelitian yang dilakukan Nguyen (2014), Chen (2014), Liem dkk (2013), Nurita dan Mawardi (2013), yang menyatakan profitabilitas berpengaruh negatif dan signifikan terhadap struktur modal, sedangkan penelitian yang dilakukan oleh Widodo dan Jawahir, Lewis dan Jais (2014), hendri dkk (2013), Khairin dan Puji Harto (2014), menyatakan bahwa profitabilitas berpengaruh positif dan signifikan terhadap struktur modal, berbeda dengan penelitian yang dilakukan oleh Jeni Anwar dkk (2014), Abiprayasa dkk (2013) dimana mereka menyatakan bahwa profitabilitas tidak berpengaruh terhadap struktur modal.

H1 : Profitabilitas berpengaruh negatif terhadap Struktur Modal.

\section{Pengaruh Tangibility terhadap Struktur Modal}

Perusahaan yang mempunyai asset yang besar tentunya adalah perusahaan skala besar dan mapan, hal ini membuat rasa aman kepada kreditur dalam memberikan pinjaman bila terjadi financial distress. Mempunyai aktiva berwujud yang besar juga dapat memberikan keuntungan dari segi perpajakan, karena adanya biaya depresiasi atas aktiva berwujud yang dapat mengurangi penghasilan kena pajak (non debt tax shield). Aktiva tetap dapat dijadikan jaminan atau collateral dalam melakukan pinjaman hutang, dan karenanya dapat mereduksi biaya dari kesulitan keuangan (cost of financial distress) dan ini akan semakin meningkatkan kapastitas tingkat hutang yang dapat menguntungkan perusahaan. Indrajaya dkk (2011).

Penelitian dari Widodo dkk (2014), Nguyen (2014, Liem dkk (2013), Rina (2014), Dewi dan Badjra (2013), Tariq et al (2013) dan Hendri dkk (2013) menyatakan banhwa tangibility berpengaruh positif dan signifikan terhadap struktur modal perusahaan, berbeda dengan penelitian yang dilakukan oleh Jeni dkk (2014), Dessy dkk, Chaerunisa dan Farah (2014), Li-Ju dan Shun-Yu, yang menyatakan bahwa struktur aktiva tidak berpengaruh signifikan terhadap struktur modal.

H2 : Tangibility berpengaruh positif terhadap

\section{Struktur Modal}

\section{Pengaruh Risiko Bisnis terhadap Struktur Modal}

Risiko yang makin tinggi akibat membesarnya hutang cenderung menurunkan harga saham, tetapi dengan meningkatnya tingkat pengembalian yang diharapkan dapat menaikkan harga saham perusahaan. Menurut Brigham dan Houston (1998: 8), risiko bisnis dipengaruhi oleh: Variabilitas permintaan (unit yang terjual), variabilitas harga jual, variabilitas harga masukan, kemampuan untuk menyesuaikan harga keluaran terhadap perubahan harga masukan, dan sejauh mana biaya-biaya bersifat tetap atau Leverage Operasi.

Apabila perusahaan mengalami kerugian atau arus kas yang masuk tidak mencukupi untuk membayar beban bunga, maka perusahaan dapat mengalami bangkrut (bankruptcy). Sesuai dengan teori trade-off, semakin tinggi kemungkinan financial distress, akan semakin tinggi pula kemungkinan financial distress costs yang harus ditanggung oleh perusahaan.

Semakin besarnya risiko bisnis disuatu perusahaan berdampak pada penurunan pembiayaan dengan hutang (struktur modal). Hal ini sejalan dengan hasil penelitian yang dilakukan oleh Jeni dkk (2014) yang menyatakan terdapat pengaruh yang negatif signifikan antara risiko bisnis terhadap struktur modal. Berbeda dengan hasil penelitian yang dilakukan oleh Tariq et al (2013) yang menyatakan bahwa risiko bisnis berpengaruh positif signifikan terhadap struktur modal. Sedangkan Glenn dkk (2011) hasil penelitian mereka menyatakan bahwa variabel risiko bisnis memiliki pengaruh positif tidak signifikan terhadap leverage.

H3 : Risiko Bisnis berpengaruh positif terhadap

Struktur Modal

\section{Pengaruh Pajak terhadap Struktur Modal}

Pajak memiliki pengaruh terhadap keputusan struktur modal. Modigliani dan Miller mengemukakan bahwa bila ada pajak maka perubahan struktur modal menjadi relevan, karena bunga yang dibayarkan berfungsi sebagai tax deductable yaitu beban yang dapat dikurangkan 
untuk tujuan perpajakan. Dalam kaitannya dengan pajak, perusahaan dapat memperoleh keuntungan pajak atas pembayaran bunga pinjaman (interest tax shield). Penelitian Anisa dan Djumahir (2014), Dewi dan Bajra (2013), menyatakan bahwa pajak berpengaruh signifikan positif terhadap struktur modal, hal ini berbeda dengan hasil penelitian Chaerunisa dan Farah (2014) yang menyatakan pajak tidak berpengaruh dengan struktur modal.

H4 : Pajak berpengaruh positif terhadap Struktur Modal

\section{Pengaruh Non Debt Tax Shield terhadap Struktur Modal}

Perusahaan dapat memperoleh keuntungan pajak selain dari pengurangan bunga atas pinjaman, yaitu disebut Non debt Tax Shield atau keuntungan pajak yang diperoleh perusahaan selain bunga pinjaman yang dibayarkan. Menurut Bradley et al (1984) Non-debt tax shield adalah dalam bentuk depresiasi aktiva tetap. Dalam Pasal 6 ayat (1) huruf b Undang-Undang Nomor7 tahun 1983 tentang Pajak Penghasilan yang telah diubah terakhir dengan Undang-Undang Nomor 17 tahun 2000 tentang Pajak Penghasilan: "Besarnya Penghasilan Kena Pajak bagi Wajib Pajak dalam negeri danbentuk usaha tetap, ditentukan berdasarkan penghasilan bruto dikurangi : biaya penyusutan atas pengeluaran untuk memperoleh harta berwujud dan amortisasi ataspengeluaran untuk memperoleh hak dan atas biaya lainnya yang mempunyai masamanfaat lebih dari satu tahun ............."

Biaya depresiasi juga mencerminkan besarnya tingkat aset berwujud yang dimiliki oleh perusahaan, aset berwujud tersebut selanjutnya dapat digunakan sebagai aset jaminan (collateral) sebagai jaminan hutang pada waktu mengajukan hutang. Perusahaan mempunyai asset kolateral yang tinggi maka perusahaan tersebut akan dengan mudah mendapatkan hutang baru sehingga ada kecenderungan untuk menambah hutang lagi. Ada beberapa hasil penelitian yang menyatakan non debt tax shield tidak memiliki pengaruh yang signifikan terhadap struktur modal, diantaranya oleh Rizky dkk (2013), dan Murhadi (2013) yang meneliti determinan struktur modal di asia tenggara. Berbeda dengan penelitian Tariq et al (2013) yang menyatakan non debt tax shield berpengaruh signifikan terhadap struktur modal pada perusahaan tekstil dan makanan di Pakistan.

H5 : Non debt tax shield berpengaruh positif terhadap Struktur modal

\section{Pengaruh Struktur Modal terhadap Nilai Perusahaan}

Menurut teori struktur modal, apabila posisi struktur modal berada diatas atau melampaui target struktur modal optimalnya, maka setiap pertambahan hutang akanmenurunkan nilai perusahaan sebaliknya Trade-off theory menjelaskan bahwa jika posisi struktur modal berada dibawah titik optimal maka setiap penambahan hutang akan meningkatkan nilaiperusahaan. Untuk itu manajemen dituntut dapat mengoptimalkan target struktur modal. Struktur modal adalah proporsi pendanaan dengan hutang (debt financing) perusahaan, Dengan demikian, hutang adalah unsur daristruktur modal perusahaan. Teori struktur modal menjelaskan bahwa kebijakan pendanaan (financial policy) perusahaan dalam menentukan struktur modal (bauran antara hutang dan ekuitas) bertujuan untuk mengoptimalkan nilai perusahaan (value of the firm). Teori trade-off memprediksi hubungan positif antara struktur modal dengan nilai perusahaan dengan asumsi keuntungan pajak masih lebih besar dari biaya tekanan financial dan biaya keagenen.

Penelitian oleh Ayu dan Ary (2013) menyatakan bahwa struktur modal berpengaruh negative dan signifikan terhadap nilai perusahaan, sedangkan penelitian yang dilakukan oleh Sari (2014), Kusumajaya (2011) Struktur modal mempunyai pengaruh positif dan signifikan terhadap nilai perusahaan, berbeda dengan penelitian yang dilakukan oleh Ginanjar dkk yang menyatakan bahwa struktur modal berpengaruh tidak signifikan terhadap nilai perusahaan.

H6 : Struktur modal berpengaruh positif terhadap nilai perusahaan 


\section{Metode}

Populasi menurut Sugiyo (2006) adalah wilayah generalisi yang terdiri atas obyek atau subyek yang mempunyai kualitas dan karakteristik tertentu yang ditetapkan oleh peneliti untuk dipelajari dan kemudian ditarik kesimpulannya. Populasi dapat berupa peristiwa, nilai, manusia, hewan, udara, gejala, tumbuh-tumbuhan, dan sebagainya, sehingga objek-objek tersebut dapat menjadi sumber data penelitian. Yang menjadi populasi dalam penelitian ini adalah perusahaanperusahaan pertambangan yang terdaftar di Bursa Efek Indonesia (BEI) periode tahun 2010 sampai dengan tahun 2014. Teknik pengambilan sampel yang digunakan adalah purpose sampling yaitu pengambilan sampel berdasarkan kriteria tertentu.

Variabel Dependen dalam penelitian ini adalah struktur modal yang diproyeksikan dengan debt to equity ratio (DER) sebagai (Y1) dan nilai perusahaan sebagai (Y2). Variabel Independen adalah variable yang dapat dipengaruhi oleh variable lain, yang termasuk variable bebas dalam penelitian ini adalah: Profitabilitas (ROE) merupakan suatu indikator kinerja yang dilakukan manajemen dalam mengelola kekayaan perusahaan yang ditunjukan oleh laba yang dihasilkan. Pada penelitian ini profitabilitas diukur dengan menggunakan proxy return on equity. Return on equity (ROE) adalah rasio antara laba bersih setelah pajak terhadap penyertaan modal. Variabel Tangibility (Tang), Perusahaan yang memiliki asset tetap lebih banyak dari pada perusahaan yang memiliki sedikit asset tetap akan memiliki akses yang lebih besar kepada kreditur, Tangibility adalah menunjukkan perbandingan aktiva tetap dengan total aktiva. Variabel Risiko Bisnis (Risk) Business risk adalah berkaitan dengan risiko operasi perusahaan yaitu risiko yang berkaitan dengan proyeksi tingkat pengembalian atas equity. Risiko bisnis atau business risk diukur dengan membandingkan laba sebelum bunga dan pajak dengan laba setelah bunga dan pajak. Variabel Pajak (Tax) Teori Modigliani dan Miller menyatakan bahwa bunga pinjaman dapat diperhitungkan sebagai biaya pengurang pajak penghasilan perusahaan, namun beban bunga yang tinggi juga dapat mengakibatkan risiko financial perusahaan semakin besar. Pajak diukur dengan membandingkan beban pajak tahun kini dengan laba sebelum pajak, dan variabel Non Debt Tax Shield (NDTS) Non Deb Tax Shield merupakan manfaat pajak yang didapat perusahaan selain dari hutang. Non debt tax shield diukur dengan membandingkan beban depresiasi dengan dengan total asset.

Penelitian ini menggunakan metode regresi berganda, yaitu metode yang digunakan untuk menganalisa hubungan antar variable. Hubungan tersebut dapat diekpresikan dalam bentuk persamaan yang menghubungkan antar variabel:

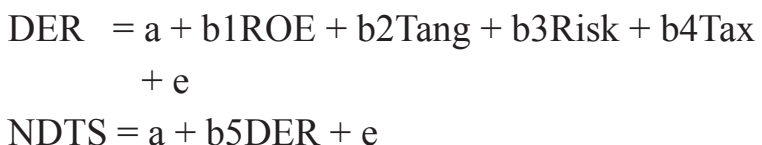

Keterangan:

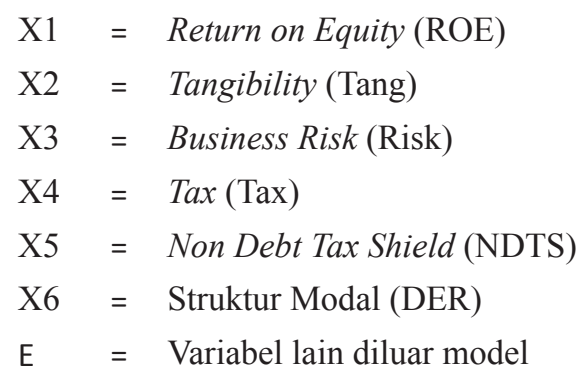

\section{Hasil Penelitian dan Pembahasan}

Tahapan penelitian dimulai sejak proses pengumpulan data, pengolahan data, pengujian data dan pengujian model. Pengujian dilakukan untuk menjamin terpenuhinya asumsi yang diperlukan untuk pengujian model regresi berganda. Tujuan penelitian ini adalah untuk mengetahui pengaruh Profitability, Tangibility, Risiko Bisnis, Tax rate dan Non debt tax shield terhadap Struktur Modal dan implikasinya terhadap Nilai Perusahaan pada perusahaan pertambangan yang terdaftar di bursa Efek Indonesia tahun 2010 sampai 2014.

\section{Pengaruh Profitabilitas terhadap Struktur Modal}

Profitabilitas adalah kemampuan perusahaan dalam menciptakan profit atau laba 
dimana dalam penelitian ini berdasarkan kemampuan perusahaan dalam hubungannya dengan equity (return on equity). Hasil penelitian ini menunjukkan dengan meningkatnya tingkat laba (ROE) perusahaan maka akan memperkecil struktur modal perusahaan pertambangan tetapi pengaruh ini tidak signifikan. Menurut pecking order theory dengan return on equity yang tinggi seharusnya dapat memperkecil tingkat utang karena kebutuhan dana investasi dapat menggunakan dana dari laba ditahan. Karena dana untuk investasi diperusahaan pertambangan sangat besar maka penggunaan utang masih sangat dibutuhkan untuk memenuhi kebutuhan pendanaan, selain itu dengan adanya laba maka perusahaan merasa mampu untuk membayar bunga pinjaman.

Pada tahun 2011 perusahaan pertambangan mengalami masa booming khususnya yang bergerak dibidang pertambangan batubara, karena pada saat itu harga komoditi batubara mencapai harga tertinggi yaitu $118 / \mathrm{mt}$ dan tingkat produksi 353 juta ton, sehingga pada saat itu return on equty perusahaan pertambangan sangat baik. Untuk meningkatkan produksi maka perusahaan pertambangan melakukan ekspansi, dana ekspansi ini kebanyakan diperoleh dari dana pinjaman. Tetapi sayangnnya pada tahun 2012 pada saat tingkat produksi tinggi justru harga komoditi khususnya batubara mengalami penurunan yang sangat signifikan. Hal ini menyebabkan tingkat debt to equty ratio pada tahun 2012 meningkat dibandingkan dengan tahun 2011, dan return on equty juga mengalami penurunan hal ini disebabkan harga mengalami penurunan, dan adanya beban pembayaran pokok dan bunga pinjaman.

Hasil penelitian ini di dukung oleh penelitian yang dilakukan oleh Liem dkk (2013), Nurita dan Mawardi (2012), Li-Ju dan shun Yu (2014), Kartika dan Dana (2014), Dwi dan Bajra (2013), widodo dkk (2014), menyatakan bahwa profitabilitas berpengaruh negatif signifikan terhadap struktur modal. Hal ini berbeda dengan penelitian yang dilakukan oleh Abiyasa dkk (2014), Ginanjar dkk (2012), Meidera Elsa Dwi Putri (2012) yang menyatakan bahwa profitabilitas berpengaruh positif tidak signifikan terhadap srtuktur modal.

\section{Pengaruh Tangibilitas terhadap Struktur Modal}

Tangibilitas diukur dengan membandingkan aktiva tetap dengan total aktiva. Hasil penelitian ini menunjukkan dengan meningkatnya tangibilitas perusahaan maka stuktur modal akan meningkat pada perusahaan pertambangan tetapi pengaruh ini tidak signifikan. Dengan semakin besar nilai aktiva tetap yang dimiliki oleh perusahaan tidak selalu menjadi jaminan bagi perusahaan untuk mudah mendapatkan utang, walaupun aktiva tetap dapat dijadikan jaminan (Collateral) kepada pihak kreditur.

Hasil penelitian ini bertentangan dengan pandangan trade-off theory dimana perusahaan yang memiliki aktiva tetap yang besar cenderung memilih sumber dana dari pinjaman, karena perusahaan memiliki jaminan asset yang lebih besar dibandingkan dengan perusahaan yang memiliki tangibility asset yang kecil. Jika perusahaan gagal dalam memenuhi kewajiban membayar utangnya, aset yang menjadi jaminan utang tersebut sulit untuk dijual oleh kreditor untuk melunasi kewajibannya. Kreditur tidak hanya melihat perusahaan memiliki aset tetap yang besar tetapi kreditur juga melihat kemampuan managemen dalam mengelolah aset tersebut bermanfaat bagi perusahaan.

Hasil penelitian ini didukung oleh hasil penelitian Chaerunisa dan Farah (2014), Jeni dkk (2014), yang menyatakan bahwa tangibilitas tidak signifikan berpengaruh terhadap struktur modal, sedangkan hasil penelitian Rista dan Bambang (2011), Dewi dan Bajra (2013), Nguyen (2014), Tariq dkk (2013), W.R.Murhadi (2011), Widodo dkk (2014), Meidera Elsa Dwi Putri (2012), Joni dan Lina (2010) yang menyatakan bahwa tangibilitas berpengaruh positif signifikan terhadap struktur modal.

\section{Pengaruh Risiko Bisnis terhadap Struktur Modal}

Business Risk atau risiko bisnis diukur dengan membadingkan laba sebelum bunga dan pajak dengan laba setelah bunga dan pajak. Hasil 
penelitian ini menunjukkan risiko bisnis tidak berpengaruh signifikan terhadap struktur modal dengan arah koefisien positif ini artinya risiko usaha naik akan menyebabkan struktur modal naik, tetapi kenaikan struktur modal ini tidak hanya dipengaruhi oleh kenaikan risiko usaha.

Risiko usaha itu ada dua, yaitu risiko financial dan risiko non financail. Jika dilihat dari risiko financial maka rata-rata risiko usaha pertambangan sangat tinggi ini disebabkan karena harga komoditi yang sangat berfluktuasi, dan investasi yang cukup besar. Sedangkan risiko non financial yaitu regulasi yang selalu berubah, kondisi alam, pencemaran lingkungan dll, tetapi dengan risiko yang dimiliki tersebut tidak menyebabkan perusahaan pertambangan mengalami kesulitan dalam mendapatkan pinjaman, hal ini dapat dilihat dari rasio hutang terhadap ekuitas yang sangat besar. Para kreditur menganggap return di perusahaan tambang khususnya migas masih menjadi primadona para investor

Hasil penelitian ini didukung oleh hasil penelitian yang dilakukan oleh Rista dan Bambang (2011), Glenn dkk (2011), Anisa dan Djumahir (2014), Joni dan Lina (2010) yang menyatakan bahwa business risk tidak berpengaruh signifikan terhadap struktur modal sedangkan penelitian yang dilakukan Bobby dkk (2014), Khairin dan Puji Harto (2014), Lim (2012) yang menyatakan bahwa Business Risk berpengaruh positif signifikan terhadap struktur modal.

\section{Pengaruh Tax rate terhadap Struktur Modal}

Tax Rate (Pajak) diukur dengan membadingkan current year's tax dengan laba sebelum pajak. Hasil penelitian ini menunjukkan dengan meningkatnya ratio pajak berpengaruh positif signifikan terhadap struktur modal artinya Tax rate (pajak) yang tinggi akan meningkatkan penggunaan hutang dalam kebijakan struktur modal. Perusahaan dapat menyeimbangkan manfaat dan pengorbanan, sehingga hutang yang berfungsi sebagai beban pengurang pajak dapat memberikan manfaat yang lebih besar dibandingkan pengorbanan.

Menurut Modigliani dan Miller bila ada pajak maka perubahaan struktur modal menjadi relevan, karena bunga atas pinjaman bisa mengurangi beban pajak perusahaan (tax deductable). Dengan berkurangnya dana yang dibayarkan untuk membayar pajak penghasilan, maka dana tersebut dapat digunakan untuk dana opersional perusahaan sehingga mengurangi pinjaman. Hal ini sejalan dengan penelitian yang dilakukan oleh Dewi dan Bajra (2013), Nguyen (2014), Tariq dkk (2013), Anisa dan Djumahir (2014) yang menyatakan bahwa pajak berhubungan positif signifikan terhadap struktur modal sedangkan penelitian yang dilakukan oleh Chaerunisa dan Farah (2014) menyatakan hal yang berbeda yaitu pajak tidak berpengaruh terhadap struktur modal.

\section{Pengaruh Non Debt tax Shield terhadap Struktur Modal}

Non debt tax shield diukur dengan membandingkan total biaya depresiasi dengan total asset. Hasil penelitian ini menunjukkan dengan meningkatnya ratio non debt tax sheild berpengaruh positif signifikan terhadap struktur modal. Arah hubungan positif ini bermakna bahwa semakin besar penghematan pajak yang bukan bersumber dari utang akan peningkatan utang. Dalam peraturan perpajakan metode penyusutan yang diperkenankan dalam penghitungan pajak berbeda dengan metode penyusutan dalam laporan komersial, maka penghematan pajak yang bukan bersumber dari utang berpengaruh terhadap besarnya utang yang akan digunakan perusahaan. Sehingga perusahaan meskipun memperoleh sedikit penghematan pajak yang bukan bersumber dari utang, mendorong perusahaan untuk tetap menggunakan utang agar memeproleh manfaat penghematan pajak maksimum.

Biaya depresiasi aktiva tetap yang besar mencerminkan besarnya tingkat aktiva tetap yang dimiliki oleh perusahaan, aktiva tetap juga dapat digunakan oleh perusahaan sebagai jaminan hutang (collateral). Semakin besar collateral akan semakin mudah bagi perusahaan dalam mendapatkan pinjaman. Penelitian ini didukung dengan penelitian yang dilakukan oleh Natasari dan Januarti (2014), Lim 
(2012) menyatakan bahwa non debt tax shield berpengaruh positif signifikan terhadap struktur modal, sedangkan penelitian yang dilakukan oleh Nurita dan Mawardi (2011), Nguyen (2014) mereka menyatakan bahwa non debt tax shield berpengaruh negatif signifikan terhadap struktur modal, hal ini berbeda dengan hasil penelitian oleh Murhadi (2011), Dessy, dkk (2012), Widodo, dkk (2014) yang menyatakan bahwa non debt tax shield tidak berpengaruh signifikan terhadap struktur modal.

\section{Pengaruh Struktur Modal terhadap Nilai Perusahaan}

Nilai perusahaan yang diproxykan dengan price book value diukur dengan membandingkan harga pasar perlembar saham dengan nilai buku per lembar saham. Hasil penelitian ini menunjukkan dengan meningkatnya struktur modal tidak berpengaruh signifikan terhadap nilai perusahaan. Sebelum mencapai tingkat yang optimal hutang diharapkan dapat meningkatkan nilai perusahaan, dan sebaliknya jika terjadi tingkat hutang melewati tingkat optimal atau financial distress cost lebih besar dari efek interest tax-shield, maka hutang akan nenurunkan nilai perusahaan, hal ini sesuai dengan teori struktur modal jika sudah mencapai titik optimal maka setiap penambahan hutang akan menurunkan nilai perusahaan. Pengaruh tidak signifikan ini disebabkan, nilai perusahaan pada perusahaan pertambangan tidak hanya dilihat dari struktur modalnya tetapi ada faktor-faktor lain, misalnya luasnya lahan yang dikuasai, adanya kontrak jangka panjang dengan pihak importir yang dapat menjamin kelangsungan produksi terserap, hal ini dapat menimbulkan sinyal positif bagi para investor.

Hal ini sejalan dengan penelitian yang dilakukan oleh Ginanjar, dkk (2012), Umi dkk (2012) yang menyatakan struktur modal tidak berpengaruh signifikan terhadap nilai perusahaan. Berbeda denga hasil penelitian yang dilakukan oleh Hermuningsi (2011), Agustina dan Ghozali (2014), Mawar, dkk (2015), Dessy, dkk (2012) menyatakan bahwa struktur modal berpengaruh positif terhadap nilai perusahaan.

\section{Simpulan, Keterbatasan, dan Implikasi Hasil Penelitian}

Berdasarkan hasil analisis selama periode pengamatan (2010-2014). Dengan menggunakan sampel penelitian sebanyak 26 emiten yang telah memenuhi syarat purposive sampling. Hasil pengujian hipotesis dengan menggunakan regresi linear berganda untuk variabel independent Profitabilitas, Tangibilitas, Business Risk, Tax Rate, Non Debt tax Shield dan regresi linear sederhana untuk variabel independent Debt to Equity. Dimana hasil penelitian ini menunjukkan bahwa:

1. Profitabilitas yang diproxykan dengan Return on Equity (ROE) tidak berpengaruh signifikan dengan arah negatif terhadap struktur modal (DER) pada perusahaan pertambangan. Berarti dengan menaiknya profitabilitas akan menurunkan struktur modal, atau semakin kecil Debt to Equty ratio maka akan menaikkan Return on equity ratio tetapi pengaruh ini tidak signifikan. Hasil penelitian ini sesuai dengan Pecking Order Theory yaitu semakin tinggi tingkat laba suatu perusahaan maka akan menurunkan tingkat penggunaan hutang karena perusahaan dapat menggunakan dana internal terlebih dahulu.

2. Tangibilitas (TANG) tidak berpengaruh signifikan dengan arah positif terhadap struktur modal (DER) pada perusahaan pertambangan. Berarti menaiknya tingkat tangibilitas tidak berpengaruh dengan menaiknya tingkat struktur modal atau sebaliknya. Hal ini disebabkan aktiva tetap besar yang dimiliki suatu perusahaan belum mampu untuk menjadikan perusahaan tersebut dengan mudah dalam mendapatkan utang, walaupun aktiva tetap dapat dijadikan jaminan (Collateral) kepada pihak kreditur.

3. Business Risk (RISK) tidak berpengaruh signifikan dengan arah positif terhadap struktur modal (DER) pada perusahaan pertambangan. Berarti naik atau turunnya tingkat risiko usaha tidak mempengaruhi tingkat struktur modal atau sebaliknya meningkat atau menurunya struktur modal 
tidak berpengaruh dengan tingkat risiko usaha. Para investor mempunyai keyakinan pada perusahaan pertambangan meskipun mempunyai risiko usaha yang tinggi dapat memberikan return yang baik. Tax Rate (TAX) berpengaruh signifikan dengan arah positif terhadap struktur modal (DER) pada perusahaan pertambangan. Berarti menaiknya current year's tax akan menaikkan tingkat struktur modal. Modigliani dan Miller menyatakan bila ada pajak maka perubahaan struktur modal menjadi relevan, karena bunga atas pinjaman bisa mengurangi beban pajak perusahaan ( tax deductable).

4. Non debt tax shield (NDTS) berpengaruh signifikan dengan arah positif terhadap struktur modal (DER) pada perusahaan pertambangan. Berarti menaiknya tingkat depresiasi aktiva tetap akan menaikkan tingkat struktur modal. Biaya depresiasi aktiva tetap yang besar mencerminkan besarnya tingkat aktiva tetap yang dimiliki oleh perusahaan, aktiva tetap juga dapat digunakan oleh perusahaan sebagai jaminan hutang (collateral). Debt to Equity Ratio (DER) tidak berpengaruh signifikan dengan arah positif terhadap Nilai Perusahaan (PBV) pada perusahaan pertambangan. Berarti jika Debt to Equity ratio naik sebelum mencapai titik optimal maka nilai perusahaan juga naik, hal ini memberikan sinyal positif bagi para investor. Dengan adanya penggunaan hutang maka dapat mengontrol managemen dalam pengendalian kas.

Peneliti telah berusaha melakukan penelitian ini dengan optimal, tetapi masih terdapat beberapa keterbatasan, yaitu periode pengamatan, penelitian ini hanya melakukan pengamatan untuk tahun 2010 sampai 2014. Penelitian ini hanya mengambil sampel perusahaan pertambangan yang terdaftar di bursa efek indonesia dari tahun 2010 sampai dengan 2014, perusahaan pertambangan yang terdaftar di BEI hanya sedikit yaitu 32 perusahaan dan waktu penelitian hanya 5 tahun. Keterbatasan penggunaan variabel akuntansi yang hanya diwakili oleh tujuh variabel yaitu debt to equity ratio, return on equity, tangibility, business risk, tax rate, non debt tax shield dan price book value. Tidak melibatkan faktor eksogen lainnya seperti sales growth, return on assets, size dan tax shield, dan lain-lain yang mempengaruhi struktur modal.

Berdasarkan analisa data dan kesimpulan yang telah dikemukakan diatas maka saran-saran yang diberikan penulis kepada para investor, perusahaan, maupun untuk pengembangan penelitian lebih lanjut. Bagi regulator (BAPEPAMLK) selaku pengawas pasar modal, sebaiknya para emiten diwajibkan menyajikan rasio-rasio keuangan sebagai informasi tambahan laporan keuangan untuk mempermudah analisa kinerja para emiten. Penelitian ini diharapkan dapat menambah kasanah ilmu pengetahuan khususnya dibidang akuntansi. Managemen dituntut untuk dapat meningkatkan hasil return yang tinggi sesuai harapan para stakeholder, untuk mencapai hal tersebut maka perusahaan pertambangan khususnya yang bergerak dikomoditi batubara melakukan ekspansi untuk menambah tingkat produksi. Untuk melakukan ekspansi perusahaan memerlukan dana, disinilah peran para manager dalam menentukan apakah kebutuhan dana untuk ekspansi tersebut menggunakan dana internal atau eksternal, karena hal ini mempengaruhi tingkat debt to equty ratio. Pada tahun 2013 disaat produksi batubara mencapai puncaknya yaitu sebesar 474 $\mathrm{mt} /$ tahun harga batubara mengalami penurunan yang sangat tajam, hal ini sesuai dengan hukum supply dan demand. Sehingga banyak perusahaan pertambangan mengalami defisit, dengan debt equity ratio yang tinggi mengakibatkan tingkat resiko juga menjadi besar. Dengan menggunakan dana dari utang perusahaan dapat memanfaatkan biaya bunga pinjaman sebagai pengurang pajak (tax deduction).

\section{Daftar Rujukan}

Anwar, J., Andini, R., \& Raharjo, K. (2015). Pengaruh Ukuran Perusahaan, Resiko Bisnis, Pertumbuhan Asset, Profitabilitas, Struktur Kepemilikan dan Struktur Aktiva Terhadap Struktur Modal Pada Perusahaan 
Manufaktur di Bursa Efek Indonesia Periode 2010-2013. Journal of Accounting, 1(1).

atas Undang-undang Nomor 7 tahun 1983 tentang

Pajak Penghasilan, PT. Mitra Info. Jakarta 2000.

Brigham,E.F dan J.F. Houston.(2006). DasarDasar Manajemen Keuangan. Edisi Kesepuluh.Jakarta: Salemba Empat

Chen, S. Y., \& Chen, L. J. (2011). Capital structure determinants: An empirical study in Taiwan. African Journal of Business Management, 5(27), 10974.

Farida, Y. N., Prasetyo, Y., \& Herwiyanti, E. (2010). Faktor-Faktor yang Mempengaruhi Struktur Modal. Jurnal Bisnis dan Akuntansi, 12(2), 81-96.

Ghozali, Imam, (2013). Aplikasi Analisis Multivariate dengan Program SPSS, Badan Penerbit Universitas Diponegoro, Semarang. Hartoyo, A. K. W., Khafid, M., \& Agustina, L. (2014). Faktor-Faktor yang Mempengaruhi Struktur Modal Perusahaan Tekstil dan Garmen di BEI. Accounting Analysis Journal, 3(2).

Hermuningsih, S. (2014). Pengaruh Profitabilitas, Growth Opportunity, Struktur Modal Terhadap Nilai Perusahaan Pada Perusahaan Publik di Indonesia. Buletin Ekonomi Moneter dan Perbankan, 16(2), 127-148.

Indrajaya, G. Herlina, dan Rini Setiadi. 2011. PengaruhStrukturAktiva,UkuranPerusahaan, Tingkat Pertumbuhan, Profitabilitas dan Risiko Bisnis terhadap Struktur Modal: Studi Empiris Pada Perusahaan Sektor Pertambangan yang Listing di Bursa Efek Indonesia Periode 2004-2007. Dalam. Akurat Jurnal Akuntansi, (6).

Izati, C., \& Margaretha, F. (2014). Faktor-Faktor yang Mempengaruhi Kinerja Keuangan Pada Perusahaan Basic Industry and Chemicals di Indonesia. E-journal Management Fakultas Ekonomi. Universitas Trisakti, 1(2), 21-43.

Kartika, I., \& Dana, I. (2015). Analisis Pengaruh Profitabilitas, Likuiditas, Ukuran Perusahaan, dan Tingkat Pertumbuhan Terhadap Struktur Modal Perusahaan FOOD AND BEVERAGES yang Terdaftar di Bursa Efek
Indonesia. E-Jurnal Manajemen Universitas Udayana, 4(3).

Khairin, M. Y., \& Harto, P. (2014). Pengaruh Growth Opportunity, Profitabilitas, Fixed Asset Ratio dan Risiko Pasar Terhadap Struktur Modal (Studikasus Perusahaan Propertidan Real Estat Yang Terdaftar Di Bei Padaperiode 2010-2012) (Doctoral Dissertation, Fakultas Ekonomika Dan Bisnis).

Kusuma, G. I., Suhadak, S., \& Arifin, Z. (2013). Analisis Pengaruh Profitabilitas (Profitability) dan Tingkat Pertumbuhan (Growth) Terhadap Struktur Modal dan Nilai Perusahaan (Studi Pada Perusahaan Real Estate And Property Yang Terdaftar Di Bursa Efek Indonesia (BEI) periode 2007-2011). Profit (Jurnal Administrasi Bisnis), 7(2).

Kusumajaya, D. K. O. (2011). Pengaruh Struktur Modal Dan Pertumbuhan Perusahaan Terhadap Profitabilitas dan Nilai Perusahaan pada Perusahaan Manufaktur di Bursa Efek Indonesia. Unpublished Thesis, Universitas Udayana, Denpasar.

Lewis, L. T. P., \& Jais, M. (2014). How do firms in country with dual-financial system determine their capital structure? Evidence from Malaysia. journal of global management.

Liem, J. H., Murhadi, W. R., \& Sutejo, B. S. (2013). Faktor-faktor yang Mempengaruhi Struktur Modal pada Industri Consumer Goods yang Terdaftar di BEI periode 20072011. Jurnal Ilmiah Mahasiswa Universitas Surabaya, 2(1), 1-11.

Lim, T. C. (2012). Determinants of capital structure empirical evidence from financial services listed firms in China. International journal of economics and finance, 4(3), 191.

Mardiyanto,Handoyo,(2009).IntisariManajemen Keuangan. Grasindo, Jakarta

Mardiyati, U., Ahmad, G. N., \& Putri, R. (2012). Pengaruh Kebijakan Dividen, Kebijakan Hutang dan Profitabilitas Terhadap Nilai Perusahaan Manufaktur yang Terdaftar di Bursa Efek Indonesia (BEI) Periode. Jurnal Riset Manajemen Sains Indonesia (JRMSI)| Vol, 3(1).

Magister Akuntansi Universitas Pancasila 
Merta Dewi, N. K. S., \& Badjra, I. B. (2014). Pengaruh Likuiditas, Profitabilitas, Tangibility Assets, Ukuran Perusahaan dan Pajak Terhadap Struktur Modal. E-Jurnal Manajemen Universitas Udayana, 3(10).

Murhadi, W. R. (2012). Determinan Struktur Modal: Studi di Asia Tenggara. Jurnal Manajemen dan Kewirausahaan (Journal of Management and Entrepreneurship), 13(2), 91-98.

Myers, S.C. 1984. The Capital Structure Puzzle, Journal of Finance 39 (3) pp. 575-592.

Myers, S.C. and Majluf, N.S., (1984): Corporate Financing and Investment Decisions when Firms have Information the Investors do not have, Journal of Financial Economics, vol.

Natasari, E. Y., \& Januarti, I. (2014). Pengaruh Business Risk, Non Debt Tax Shield, Dividend Payout Ratio Dan Tangibility Asset Terhadap Penggunaan Hutang (Studi Empiris Pada Perusahaan Manufaktur Yang Go Public Di Bursa Efek Indonesia Tahun 2010-2012) (Doctoral Dissertation, Fakultas Ekonomika Dan Bisnis).

Nguyen, D. (2013). Determinants of Capital Structure in Vietnam. ssrn.com.

Nurita, D., \& Mawardi, W. (2012). Analisis Pengaruh Profitabilitas, Firm Size, Non Debt Tax Shield, Dividen Payout Ratio dan Likuiditas Terhadap Struktur Modal (Pada Perusahaan Manufaktur yang Terdaftar di Bursa Efek Indonesia Periode Tahun 2007-2010) (Doctoral dissertation, Fakultas Ekonomika dan Bisnis).

Pangulu, A. L., \& Maski, G. (2014). Pengaruh Profitabilitas, Growth Opportunity, dan Struktur Modal Terhadap Nilai Perusahaan (Studi Pada Perusahaan Perbankan yang Terdaftar di BEI Periode 2011-2013). Jurnal Ilmiah Mahasiswa FEB, 3(1).

Putri, M. E. D. (2013). Pengaruh Profitabilitas, Struktur Aktiva dan Ukuran Perusahaan terhadap Struktur Modal pada Perusahaan Manufaktur Sektor Industri Makanan dan Minuman yang Terdaftar di Bursa Efek Indonesia (BEI). Jurnal manajemen, 1(01).

Rahmawati, A. D. (2015). Pengaruh Ukuran
Perusahaan, Profitabilitas, Struktur Modal, Dan Keputusan Investasi Terhadap Nilai Perusahaan (Studi pada Perusahaan Sektor Properti, Real Estate, dan Building Construction yang Terdaftar di Bursa Efek Indonesia (BEI) Periode 2010-2013). Jurnal Administrasi Bisnis, 23(2).

Riyanto, Bambang. (2001). Dasar-Dasar Pembelanjan Perusahaan, Yogyakarta: BPFE Ross, Westerfield, Jaffe. (2005). Corporate Finance. Seventh edition. Mc Graw-hill.

Santika,R.B.,\&Sudiyatno,B.(2011).Menentukan struktur modal perusahaan manufaktur di Bursa Efek Indonesia. Dinamika Keuangan dan Perbankan, 3(2).

Sari, A. D. K. (2016). Determinan Struktur Modal Pada Perusahaan Manufaktur yang Tercatat di Bursa Efek Indonesia. Jurnal Ilmiah Mahasiswa FEB, 3(2).

Sari, D. H., Djazuli, A., \& Aisjah, S. (2013). Determinan Struktur Modal dan Dampaknya terhadap Nilai Perusahaan (Studi pada Perusahaan Makanan dan Minuman di Bursa Efek Indonesia). Jurnal Aplikasi Manajemen, 11(1), 77-84.

Tariq, W., Ali, I., Usman, H. M., Abbas, J., \& Bashir, Z. (2013). Empirical Identification of Determinants of Firm's Financial Performance: a Comparative Study on Textile and Food Sector of Pakistan. Business and Economic Research, 3(1), 487.

Undang-undang Republik Indonesia Nomor 17 Tahun 2000 tentang Perubahan Ketiga

Weston, J.F., dan Brigham, E. 1993. Managerial Finance (Manajemen Keuangan). Jakarta :7 ed. Penerbit Erlangga.

Widodo, M. W., \& Djawahir, A. H. (2014). Pengaruh Tangibility, Profitabilitas, Pertumbuhan Perusahaan, Non Debt Tax Shields, Cash Holding danUkuranPerusahaan terhadap Struktur Modal Perusahaan (Studi pada Perusahaan Manufaktur yang Listing di BEI Tahun 2010-2012). Jurnal Aplikasi Manajemen, 12(1), 143-150.

Wirajaya, A., \& Dewi, A. S. M. (2013). Pengaruh Struktur Modal, Profitabilitas dan Ukuran Perusahaan pada Nilai Perusahaan. E-Jurnal 
Jurnal Riset Akuntansi dan Perpajakan JRAP Vol. 3, No. 2, Desember 2016, hal 251-263 ISSN $2339-1545$

Akuntansi, 4(2), 358-372. 